\title{
РЕНЕССАНС ГНОСТИЦИЗМА В ГОСУДАРСТВЕННО-ПРАВОВЫХ УЧЕНИЯХ ЕВРОПЫ ХVIII В.
}

\section{THE RENAISSANCE OF GNOSTICISM IN THE STATE-LEGAL TEACHINGS OF EUROPE OF THE XVIII CENTURY}

\section{A. Palyulin}

Summary: The Gnostic ideas of knowing absolute truth through divine revelation overcame the «dark ages» of the Middle Ages and found their rebirth in the Age of Enlightenment. Studies of «ideal law» and the ideal concept of the state led to the return of European thinkers of the Enlightenment to Gnostic concepts. The relationship between morality, positive law, divine and natural law was the subject of the search for lawyers of the 18th century. Power and state, subordination and coercion were rethought through the prism of Gnosticism.

Keywords: gnosticism, Jesuits, Catholicism, Protestantism, revolution, Suarez, theology, Haskala, Christianity.

\author{
Палюлин Антон Юрьевич \\ аспирант, Национальный исследовательский \\ университет - Высшая школа экономики \\ Anton.Palyulin@gmail.com
}

Аннотация: Гностические идеи познания абсолютной истины путем божественного откровения преодолели «темные века» средневековья и нашли свое второе рождение в эпоху Просвещения. Исследования «идеального права» и идеальной концепции государства привело к возвращению европейских мыслителей эпохи Просвещения к гностическим концепциям. Соотношения морали, позитивного права, божественного и естественного права были предметом поиска юристов XVIII века. Власть и государство, подчинение и принуждение заново переосмыслялись через призму гностицизма.

Ключевые слова: гностицизм, иезуиты, католицизм, протестантизм, революция, Суарес, теология, Хаскала, христианство.
3 начение Просвещения трудно переоценить в правовом, общественном, научном, политическом, а также в эзотерическом смысле, поскольку влияние эзотерики на политику и право в XVIII в. было очень велико. Л.М. Мартинес Отеро так объясняет значение эпохи Просвещения:

«В похожем смысле Г.Э. Лессинг (1729-1781), один из главнейших столпов Просвещения, полагает, что все религии - не более чем этапы, ведущие к еще более совершенной религии. Перефразируя Иоахима Флорского, мы имеем языческие религии, которые со временем превзошел более совершенный иудаизм; в свою очередь иудаизм был превзойден еще более совершенным христианством, и, наконец, христианство будет превзойдено новой религией, которая придет вслед за ним и достигнет максимального совершенства» [1].

Довольно ярко на появление «светочей» Просвещения отреагировала Синагога, в которой в конце XVIII века появилось движение «Хаскала» (древнеевр.: «культура», «цивилизация», «просвещение»). Учитывая, что в целях самосохранения национальные диаспоры зачастую порождают самые крайние интернационалистские воззвания, этот факт особенно важен. Парадоксальная для иудаизма, Хаскала в высшей степени интернационалистична и выполняет функции ассимиляции. Если ортодоксальные евреи возводят вокруг своей диаспоры, своего гетто, стену, которую удерживает жертвоприноситель кашер («мясник»), защищая народ Торы от любого христианского загрязнения, Хаскала способствует всеобщему единению и слиянию культур. Хаскала, таким образом, -светский ответ интернациональной революции на национально-религиозную обособленность иудеев, так же, как и течения иллюминатов - ответ христианству. Иудеи из числа последователей Хаскалы добиваются включения в программу религиозных школ мирских предметов, в частности юриспруденции, и изучения языка страны, в которой эти школы находятся. Особенных успехов Хаскала добилась в Германии и Австро-Венгерской империи, вплоть до того, что идиш и ладино, «эти языки коверкания и упадка» [1], стали сильно коверкаться местными евреями. Вместе с тем, растет собственная религиозность евреев и интерес к древнееврейскому языку, будущему языку возрожденного государства Израиль, что стало несомненным успехом Мозеса Мендельсона, основателя Хаскалы.

Ученики Мендельсона из берлинской Хаскалы пошли еще дальше, отказавшись от еврейской религиозности и объединившись с большинством гностиков Европы в идее «гражданской религии», деизма и индивидуального познания Бога. Это предопределило зарождение глобализма в еврейской среде, что вылилось в итоге в активное участие евреев в политической жизни многих стран Европы и Нового света, а также в образовании государства Израиль.

Гностические настроения Возрождения и Нового времени вылились в массовое создание так называемых 
«обществ посвященных». Эпоха Возрождения стала знаковой для науки и философии. Именно во время Ренессанса у людей проснулся интерес к древним знаниям. К ним стоит отнести не только философские размышления древних греков или научные изыскания ученых Античности, но и прежде всего - сакральное знание, которое, по мнению мыслителей, отринувших христианскую догму, может принести универсальное и совершенное знание об идеальном устройстве государства, поведении человека в нем, о наилучших законах и о сущности и смысле бытия в целом. Поиски этого универсального знания оборачивалось довольно серьезными социальными экспериментами, выливавшиеся в революции и гонения.

Как это ни удивительно, но ближе всего к реализации управления обществом в соответствии с гностическими идеалами в эпоху Просвещения подошли именно Общество Иисуса или иезуиты, христианский воинствующий орден, из чьей системы образования вышел Адам Вейсгаупт. Иезуитами было осуществлено расселение индейцев гуарани Парагвая в организованные самодостаточные фаланстерские республики. В них индейцы жили в относительной свободе от европейских колонистов, хотя и платили установленные налоги.

Подробно фаланстерские республики как идеал утопического социализма описаны в работах Шарля Фурье, в частности, в двухтомном «Трактате о домашней и земледельческой ассоциации». Центром культурной и политической жизни подобной республики был фаланстер - большое здание, в котором находились библиотеки, залы, столовые, гостиные, мастерские и прочие помещения для совместного времяпрепровождения.

Подобных республик было около 30 на территории Парагвая. Главным зданием в них была церковь, также большую роль в общественной жизни играла школа, в которой давали бесплатное гуманистическое религиозное образование. Иезуитам, обособивших индейцев от пороков европейского общества, удалось создать гностическую утопию: каждый индеец был лично неприкосновенен, владел частной собственностью и, помимо физического труда, занимался собственным просвещением. Около 50 иезуитов управляли таким образом около 140000 индейцами гуарани. Иезуиты создали государство, которое защищало гуарани не хуже любого европейского, если не считать набегов португальских пиратов и деятельности испанских уполномоченных. После издания Прагматической санкции об изгнании иезуитов из всех владений испанской короны и конфискации их имущества от 2 апреля 1767 года королем Карлом III, индейцы вернулись в сельву или переехали в БуэносАйрес, чтобы заниматься ремеслами, которыми они обучились у иезуитов.
Официальными обвинениями против иезуитов в Прагматической санкции являются [2]:

- независимый деспотичный режим в Парагвае;

- вмешательство в политическую жизнь;

- антиправительственные и антикоролевские речи на своих собраниях;

- подготовка восстаний туземцев;

- антиправительственный заговор в Маниле.

Кроме того, упоминались такие «грехи» иезуитов как осуществление власти над испанской знатью путем принятия исповедей. Менее формальными причинами, повлекшими за собой гнев светских властей, явились монополия иезуитов в образовательной сфере и подчинение напрямую Папе путем личной прелатуры.

Слепое подчинение иезуитов своему генералу было необходимо для функционирования Общества Иисуса точно так же, как оно необходимо для функционирования армии. Вейсгаупт перенимает такой порядок у иезуитов, совершенствуя систему внутренней работы Общества. Обязательная устная исповедь братьям (как это практиковалось, к примеру, у тамплиеров) у иезуитов были превращены Вейсгауптом в систему доносов.

Согласно выводам А.Г. Дугина, иезуиты являлись прямыми наследниками тамплиеров. Такие внешние атрибуты как военная форма организации ордена, братские исповеди и воинствующая христианская идеология служат тому доводом. [3] Более того, ссылаясь на Рене Генона, А.Г. Дугин полагает, что Общество Иисуса является планом мести Ордена Храма, влиявшего на баварских иллюминатов, готовивших почву для антимонархических восстаний во Франции, а затем - в остальной Европе. [4] В связи с этим в инициалах подписи Ордена Иисуса в целом и иезуитов в частности S.I. (Societas lesu, Общество Иисуса) усматривается ссылка на Высших Неизвестных S.I. (Superieurs Inconnus), упоминавшихся в различных мистических антимонархических послушаниях.

Девиз «цель оправдывает средства», приписываемый и иезуитам, и иллюминатам, часто звучала в трактатах Возрождения. [5] Этот основной политический тезис был увязан иезуитами с религиозной доктриной. Ими была разработана доктрина пробабилиоризма, в теологии означавшей необходимость следовать «более вероятной» доктрине (лат.: probabilior) в случае сомнения в какихлибо теологических доводах. Поскольку человек может сомневаться, то во избежание греха предусмотрительность требует обратиться к той доктрине, которая предоставит наименьшую возможность ошибиться. Такая точка зрения предусматривает, что при наличии возможности хотя бы минимального шанса избежать смертного греха и достичь благой цели, надо действовать.

Такая казуистика давала орденам возможность дей- 
ствовать, не оглядываясь на нормы морали и религии, изучать запретные знания, действовать небиблейскими методами и совершать дурные действия с добрыми намерениями. Особенно широко практиковал подобные идеи Адам Вейсгаупт и иллюминаты.

Подобная идеология характерна для гностических обществ, вынужденных действовать в «падшем» и греховном мире. И действительно, любое действие гностика, направленное на достижение, по его мнению, доброго результата, будет допустимым в мире зла.

Другим видным сторонником иезуитской методологии, кроме Адама Вейсгаупта, был Франсиско Суарес - светоч своей эпохи. В XVII веке он являлся самым стойким последователем средневековой схоластики и был поистине выдающимся ученым. Он изучал юридические науки в Саламанкском университете, затем вступил в орден иезуитов и был профессором богословия в Сеговии, Алкале, Саламанке и Риме. Политический памфлет Франсиско Суареса «Defensio fidei catholicae contra anglicanae sectae errores», изданный по предложению папы Павла V был направлен против политики Иакова І. Непримиримый борец с инакомыслием и ересью, он был сторонником старых схоластических методов мышления со ссылками на авторитеты (правда, уже схоластические, а не Аристотеля) и опорой на силлогизмы. [6]

Одним из основных трактатов Суареса - сочинение «De legibus», в котором он близко следует Фоме Аквинскому. Данный трактат является образцом и венцом схоластической мысли. В нем в энциклопедическом порядке подведен итог средневекового знания, в том числе и юридического. Согласно Франсиско Суаресу, существует два вида законов: закон естественный и закон положительный; первый относится к предмету ведения морали, второй составляет - основную проблему политики. [7] Схоласты выделяли два рода естественных законов: закон указующий (lex indicativa) и закон предписывающий (praeceptiva); первый ограничивается разъяснением того, что хорошо и что дурно, второй повелевает делать или не делать то или иное. Схоластические авторитеты, таким образом, делятся в этом отношении на два лагеря: одни признают естественный закон исключительно индикативным, другие - исключительно прецептивным. Суарес придерживается «золотой середины» и полагает, что в естественном законе находятся явно оба свойства. Естественный закон по Суаресу и разъясняет, и повелевает в одно и то же время. Такой ответ на основную проблему заставляет Суареса искать выхода из другой схоластической антиномии, плотно связанной с предыдущей. На чём покоится естественный закон: на природе вещей или на божественном велении? Суарес одинаково чужд как рационализма, так и провиденциализма в их чистом виде и принимает в качестве источника естественного закона как человеческий разум, так и божественную волю [8].

На этих основах покоится и политика Суареса. Так как общество - естественное состояние человека, вне которого он не может жить, то тем самым оно является учреждением божественным; но так как общество не может существовать без законов, а законы не могут явиться без власти, их издающей, то есть без правительства, то и правительство - институт божественный. Божественность верховной власти, по Суаресу, является результатом её естественного происхождения; слова апостола Павла «Всякая власть от Бога» необходимо понимать исключительно в этом смысле, а не так, что в возникновении верховной власти кроется непостижимое человеческому разуму происхождение, непосредственная её божественная делегация. Так как власть порождена естественным законом, то она и подчиняется ему; возникшая для нужд общества, она покоится на акте делегации от исторического и реального общества. Словом, верховная власть принадлежит народу и им делегируется правительству; но такая делегация не составляет необходимости: общество (народ) может сохранить власть за собой, и это решение будет столь же законно, как и решение делегировать власть одному лицу или нескольким лицам, на время или навсегда. Не отрицая принципиально ни одной из возможных форм правления, Суарес из соображений практических склоняется на сторону монархии. Но так как монарх — не является божественным ставленником, а лишь представителем народа, то он должен сообразоваться с народной волей; согласие суверена и народа является уникальным источником власти монарха; наследственность трона обусловливается сохранением этого согласия. Как только оно прекращается, верховный суверен - народ - вступает в свои права; а права у него, по Суаресу, в данном случае очень широки. Законному монарху он может оказать лишь пассивное сопротивление, но по отношению к узурпатору, тирану в античном смысле слова, дозволены всякие меры, не исключая убийства. Убийство не возбраняется даже тогда, когда виновным в нарушении законов оказывается законный монарх, но Суарес советует избегать этого, если нарушены интересы не всего общества, а лишь частного лица. Тирана же может убить последний гражданин за всякое нарушение закона.

Политическая доктрина Суареса имела ряд последователей. Начало XVII в. было эпохой острого политикорелигиозного кризиса, когда приходили в столкновение самые разнородные интересы, когда оппозиция против абсолютизма, более или менее прикрытая религиозными мотивами, явно или скрыто действовала во всей Западной Европе. Абсолютизм мешал католикам, потому что в своём развитии подрывал идею авторитета папы, - мешал и различным протестантским партиям, потому что подавлял свободу мысли. Поэтому учение монархомахов, одним из видных представителей которого был 
Суарес, вербовало своих сторонников как в среде католических, так и в среде протестантских публицистов. В частности, доктрина тираноубийства, первое выражение которой мы встречаем ещё в Средние века, была чисто католической и в эпоху религиозных войн имела многих представителей (Буше, Мариана), кроме Суареса. Она не оставалась только книжной, а проводилась в жизнь, деятельно пропагандируемая иезуитами. Убийство Вильгельма Оранского в Нидерландах (1584) и двух Генрихов во Франции (1588 и 1610) стояло в связи с этой пропагандой. [9]

Некоторое время Суарес подозревался в ереси, поскольку поддерживал тезисы иезуита Луиса Молины. Против этого учения, как противоречащего учению Фомы Аквинского, выступили доминиканцы, но многие иезуиты выступили на стороне молинистов. Однако, все они, в том числе Суарес и Молина, были оправданы Святейшим престолом. В 1598 году для разрешения спора Папа Климент VIII назначил в 1598 г. Конгрегацию помощи благодати («Congregatio de auxiliis gratiae»), упраздненную Папой Павлом V в 1607 г.

Луис Молина был учителем богословия в Эворе и Мадриде; он стал знаменит благодаря своему тракта- ту «Liberi arbitrii cum gratiae donis etc. concordia» о coгласии свободной воли человека с дарами благодати и с божественным предопределением. В этом трактате Молина пытался примирить учение иезуитов со схоластикой Фомы Аквинского. Молина отвергал божественное предопределение вообще, и более того - ослаблял значение благодати до минимума. [10] Возвеличение роли свободной воли человека в его судьбе роднит молинистов с лютеранами. Однако Конгрегация помощи благодати была упразднена в 1607 году, не разрешив вопрос о соотношении свободной воли с божественным предопределением, сомнения просвещенного мира относительно роли Бога в земной истории обществ и государств также не были разрешены.

Очередное сближение католического клира с гностическими учениями вызвано растущими в Европе гностическими настроениями. Идеи социального равенства, свободы воли человека, нежелание паствы признавать клир, злоупотребляющий своей духовной властью, приводят к отрицанию Церкви через гностицизм и атеизм. Отрицание Церкви, в свою очередь, приводит к распространению новых государственно-правовых учений, качественно иным образом, определяющим роль государства и права в жизни общества.

\section{ЛИТЕРАТУРА}

1. Отеро, Л.М.М. Тайные общества / Луис Мигель Мартинес Отеро. - М.: Евразия, 2008, 508 стр. - С. 178.

2. Planas, Enrique. Los jesuitas en el Río de la Plata: historia de las misiones en la época colonial. Colección Antorcha. Autor: Enrique Planas. Editor: Atlántida, S.A., 1941, p.116.

3. Генон, Р. Символы священной науки / Р.Генон. - М.: Беловодье, 2002, 496 стр. - С.40-44.

4. Дугин А. Конспирология: великая война континентов / А. Дугин - М.: Арктогея 2005, 223 стр.

5. Великович Л.Н. Черная гвардия Ватикана / Л.Н. Великович - М., 1985, 288 стр.

6. Suárez Francisco. Defensio fidei catholicae et apostolicae adversus Anglicanae sectae errors / Francisco Suárez. - Madrid: Itziar Arranz Libros, 1872 , p.321.

7. Suárez Francisco. Tractatus de legibus ac deo legislatore: in decem libros distributus/ Francisco Suárez. - Naples: ex typis Fibrenianis, 1872, p.678.

8. Черняков А.Г. Учение Суареса о сущности и существовании в интерпретации Мартина Хайдеггера / А.Г. Черняков // Verbum. Альманах центра изучения средневековой культуры. Вып.І. Франсиско Суарес и европейская культура XVI-XVII веков. - СПб., 1999, 200 стр. - С.25-43.

9. Черняк Е.Б. Вековые конфликты / Е.Б. Черняк. - М.: Международные отношения, 1988, 400 стр.

10. Molina Ludovico. Concordia liberi arbitrii cum gratiae donis, divina praescintia, providential, praedestinatione, et reprobation, ad nonnulos primae partis D. Thomae articulos / Ludovico Molina. - Lisbon: Olyssipone, 1588, p.668.

(с) Палюлин Антон Юрьевич (Anton.Palyulin@gmail.com) 